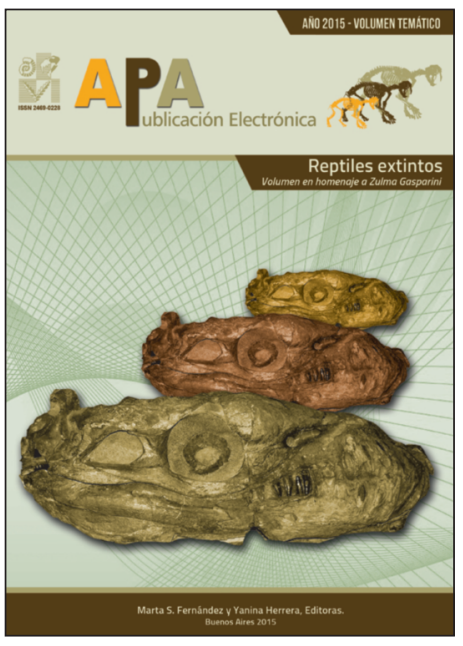

\title{
THE LOST WORLD OF GEORGES CUVIER: MOSASAURIDS FROM THE CAMPANIAN MEUDON CHALK (FRANCE)
}

NATHALIE BARDET 1

ALAIN GALOYER ${ }^{2}$

\footnotetext{
'Sorbonne Universités, CR2P CNRS-MNHN-UPMC, Département Histoire de la Terre, Muséum National d'Histoire Naturelle, CP 38,57 rue Cuvier, 75005 Paris, France.

${ }^{2} 91$ rue de Paris, 92190 Meudon, France.
}

Recibido: 20 de agosto 2015 - Aceptado: 21 de octubre 2015

Para citar este artículo: Nathalie Bardet y Alain Galoyer (2015). The lost world of Georges Cuvier: mosasaurids from the Campanian Meudon Chalk (France). En: M. Fernández y Y. Herrera (Eds.) Reptiles Extintos - Volumen en Homenaje a Zulma Gasparini. Publicación Electrónica de la Asociación Paleontológica Argentina 15(1): 58-68.

Link a este artículo: http://dx.doi.org/10.5710/PEAPA.20.08.2015.99

DESPLAZARSE HACIA ABAJO PARA ACCEDER AL ARTÍ́CULO

Asociación Paleontológica Argentina Maipú $6451^{\circ}$ piso, C1006ACG, Buenos Aires República Argentina Tel/Fax (54-11) 4326-7563 Web: www.apaleontologica.org.ar

Otros artículos en Publicación Electrónica de la APA 15(1):

\section{de la Fuente \& Sterli}

ESTADO DEL CONOCIMIENTO DE LAS TORTUGAS EXTINTAS DEL TERRITORIO ARGENTINO: UNA PERSPECTIVA HISTÓRICA.

\section{Paulina Carabajal}

GUIA PARA EL ESTUDIO DE LA NEUROANATOMÍA DE DINOSAURIOS SAURISCHIA, CON ENFASIS EN FORMAS SUDAMERICANAS.

\section{Pol \& Leardi}

DIVERSITY PATTERNS OF NOTOSUCHIA (CROCODYLIFORMES, MESOEUCROCODYLIA) DURING THE CRETACEOUS OF GONDWANA. 


\title{
THE LOST WORLD OF GEORGES CUVIER: MOSASAURIDS FROM THE CAMPANIAN MEUDON CHALK (FRANCE)
}

\author{
NATHALIE BARDET ${ }^{1}$ AND ALAIN GALOYER ${ }^{2}$
}

'Sorbonne Universités, CR2P CNRS-MNHN-UPMC, Département Histoire de la Terre, Muséum National d'Histoire Naturelle, CP 38, 57 rue Cuvier, 75005 Paris, France.bardet@mnhn.fr

291 rue de Paris, 92190 Meudon, France.

\begin{abstract}
The Late Campanian white Chalk of Meudon, a city located in the suburbs of Paris (France), has yielded during the $19^{\text {th }}$ century several mosasaurid remains consisting mainly in isolated teeth, most being nowadays lost. These specimens, which history is associated to the most famous French palaeontologists of that time like Georges Cuvier, Paul Gervais and Albert Gaudry, represent the earliest mosasaurid discoveries from France. As such, they are precious and unique witnesses of a lost world. In this paper, an historical approach has been privileged, focusing on the history of their discovery and how they were originally perceived and interpreted by Cuvier and others. On a systematical point of view, the material is referred mostly to indeterminate species of the tylosaurine genus Hainosaurus but also of the plioplatecarpine Plioplatecarpus and possibly of the mosasaurine Prognathodon, attesting of the occurrence of the three major clades of mosasaurids in this Late Campanian marine vertebrate fauna of France.
\end{abstract}

Key words. Mosasaurids. Campanian. Chalk. Meudon. France.

Resumen. EL MUNDO PERDIDO DE GEORGES CUVIER: LOS MOSASAURIOS DE LA CRETA CAMPANIENSE DE MEUDON (FRANCIA). La Creta blanca de edad Campaniense superior de Meudon, una ciudad situada en las afueras de París (Francia), ha proporcionado durante el siglo XIX diversos restos de mosasaurios que consisten esencialmente en dientes aislados, la mayoría de ellos hoy con paradero desconocido. Estos especímenes, cuya historia está asociada con los más famosos paleontólogos franceses de la época, como Georges Cuvier, Paul Gervais y Albert Gaudry, representan los más antiguos descubrimientos de mosasaurios en Francia. Como tales, son testimonios históricos valiosos y únicos de un mundo perdido. En este trabajo, se ha privilegiado un enfoque histórico, centrado en la historia de su descubrimiento y cómo fueron originalmente percibidos e interpretados por Cuvier y otros naturalistas. Desde un punto de vista sistemático, el material se asigna en su mayoría a especies indeterminadas del tilosaurino Hainosaurus, pero también del plioplatecarpino Plioplatecarpus y posiblemente del mosasaurino Prognathodon, lo que refleja la presencia de los tres clados mayores de mosasaurios en esta fauna de vertebrados marinos del Campaniense superior de Francia.

Palabras clave. Mosasaurios. Campaniense. Creta. Meudon. Francia.

MOSASAURIDS, a highly diversified and widespread clade of marine squamates living during the Late Cretaceous (i.e., Bardet et al., 2014) are known in France by numerous specimens (see Bardet, 2012 for a review). In the Paris Basin, several outcrops are known but, since the $19^{\text {th }}$ century, very little attention has been paid to that of Meudon, despite its historical significance that will be point out here.

The city of Meudon (Hauts-de-Seine Department, Ilede-France Region) is located in the close Southwestern suburbs of Paris, cradle of French Impressionism (Fig. 1.12). Meudon locality is famous for the production of the Blanc de Meudon (also called Meudon White, Paris White or Spain
White), a substance obtained by mixing crushed chalk with water and having a wide range of uses. Meudon is also well known by paleontologists since the $19^{\text {th }}$ century for two vertebrate-bearing geological formations, the Campanian Chalk and the Sparnacian Conglomerate (i.e., d'Orbigny, 1836) (Fig. 1.3).

At Meudon and neighbouring cities like Issy-lesMoulineaux, Bougival, Port-Marly, and Louveciennes, better known by Impressionist paints of Sisley (Fig. 1.4) and Monet, the Late Cretaceous Chalk is a very pure white chalk (Bardet and Buffetaut, 2011). It is exploited since at least the $18^{\text {th }}$ century and quarried in an extensive network of under- 
ground galleries. At this time, the chalk exploitations were open-air but they rapidly became underground due to the scarcity of available extraction surface in the Meudon area. The first underground galleries were chaotic in organization and relatively small (2-3 m high) but later, due to stricter Engineering rules to reduce accidents, new requirements for a more rational and safer exploration of the quarries were applied, such as for example a more regular gallery network, largest dimensions for the galleries $(6 \mathrm{~m}$ high and $5 \mathrm{~m}$ wide), etc. In the $19^{\text {th }}$ century, the quarry exploitation reached its apogee in the Meudon region, with several factories functioning, and an extensive network of underground galleries developed on four levels and more than $8 \mathrm{~km}$. Around 1930, the exploitation of the chalk was gradually
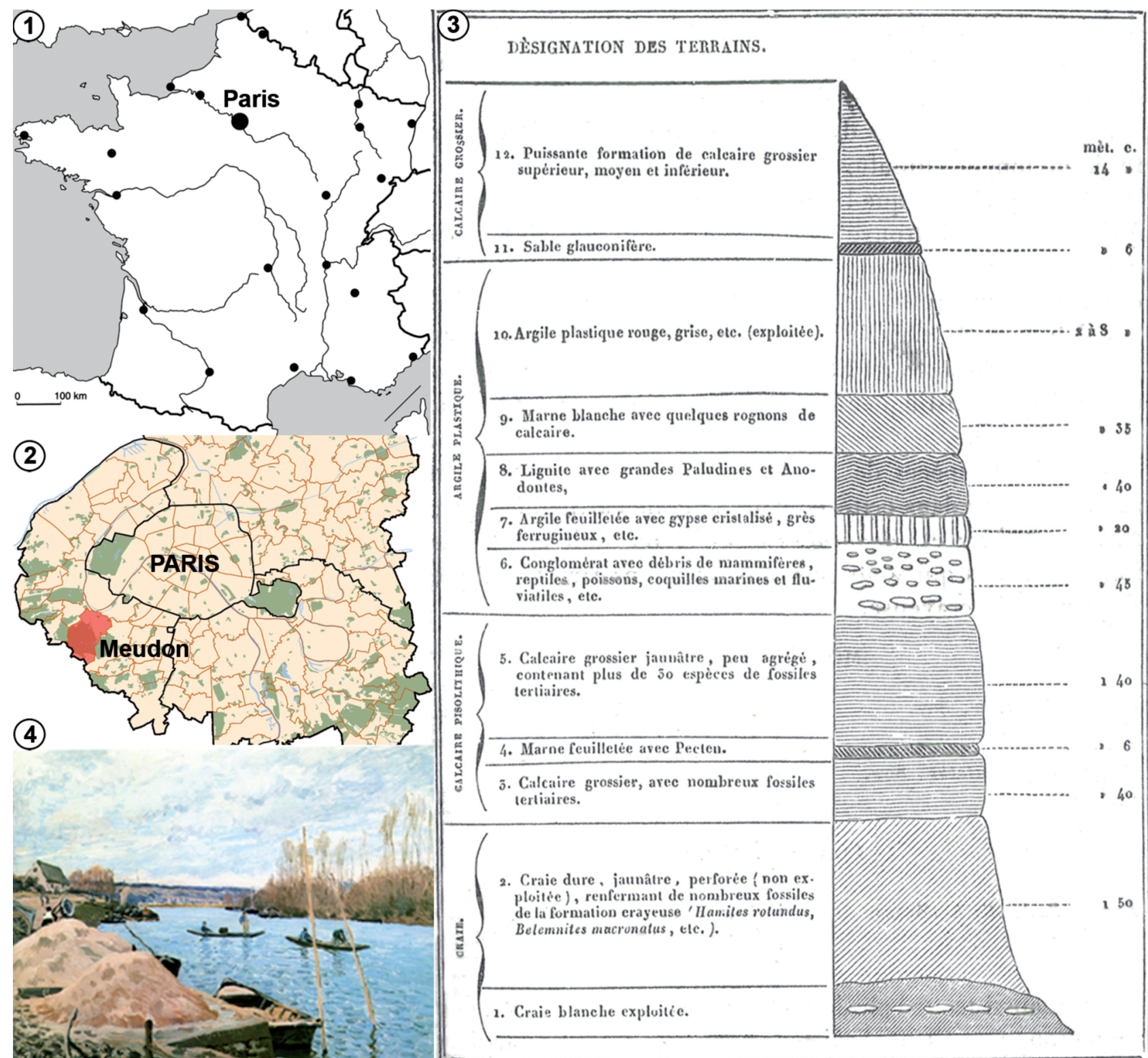

Figure 1. Geographical and stratigraphical locations of the Meudon Chalk (France). 1-2, map of France with details of the Paris region and the location of the city of Meudon (in red) in its southwestern suburb (from Wikipedia); 3, synthetic stratigraphical column of the Mesozoic and Cenozoic sedimentary rocks around Paris (from d'Orbigny, 1836). The lowermost level is the Upper Campanian White Chalk that crops out at Meudon; 4, Alfred Sisley's painting 'La Seine à Port-Marly' (1875 - The Art Institute, Chicago, USA) showing an unusual landscape that should have been very similar in Meudon: the Seine banks not as a leisure place but as an industrial one with rock exploitation. 
abandoned and the galleries converted into either wine cellars or reused for cultivation of Paris' mushrooms (until the 1950s). Today, although some of the quarries in neighbouring towns are still used as wine cellars or storage spaces, those at Meudon are abandoned and closed to the public but there are local interests to save and consider them as a natural and human heritage.

The Meudon Chalk is Late Campanian in age (Belemnitella mucronata Zone) and contains abundant invertebrate fossils, including sponges, annelids, echinoids, brachiopods, bryozoans, bivalves, belemnites and ammonites, as well as scarcer vertebrate remains firstly listed by Hébert (1855), including mainly selachian teeth. As an example, the holotype of the sawfish Onchosaurus (in Gervais 1848-1852) comes from here (Cappetta, 1987; Corral et al., 2012). As cited by d'Orbigny (1836), the faunal list also includes fish as well as reptile remains, including 'crocodilian teeth' (most probably mosasaurid ones), turtles, as well as an Iguanodonlike dinosaur, which report has never been substantiated (E. Buffetaut, pers. comm.). The vertebrate fauna from the Meudon Chalk is much in need of revision, as it has not been studied since the end of the $19^{\text {th }}$ century.

The aim of this paper is to make an historical overview of the mosasaurid remains found in the Meudon Campanian Chalk, some being preserved in the collections of the Muséum National d'Histoire Naturelle (MNHN) of Paris (France), other being lost (or not currently found).

\section{HISTORICAL ACCOUNT}

Several mosasaurid remains were found in the Meudon Campanian Chalk. Though they are mainly isolated teeth and jaw fragments, they are historical specimens representing the earliest mosasaurid discoveries from France. They are also associated to most famous French naturalists and palaeontologists of the $19^{\text {th }}$ century. Indeed, most specimens have been found by Alexandre Brongniart and Charles d'Orbigny (brother of Alcide) and described by Georges Cuvier (1824, 1836), Paul Gervais (1848-1852), Edmond Hébert (1855) and Albert Gaudry (1892). The remains were generally referred at this time to either Leiodon anceps (now considered a nomem dubium, Schulp et al., 2008) or Mosasaurus camperi (= Mosasaurus hoffmannii Mantel, 1829), but a recent review referred most of them to Hainosaurus sp. (see Bardet, 2012).

\section{The Georges Cuvier's tooth: the first mosasaurid described from France}

MNHN 8711 (Fig. 2.1-2) is preserved in the MNHN collections of Paleontology. It represents the first mosasaurid remain to have been found and described from France. It has been found in the Meudon Chalk by the naturalist Alexandre Brongniart, friend of Georges Cuvier. Together, they worked from 1804 to 1808 on a monumental work, their Essai sur la géographie minéralogique des environs de Paris accompanied by a splendid hand-colored geological map of the Paris Basin (Cuvier and Brongniart, 1811) whose ambition was to identify and map all the sedimentary formations of the Paris Basin (see Taquet, 2009 for details). It is probably during one of his numerous geological fieldtrips around Paris that Alexandre Brongniart discovered this tooth.

It was described by the famous anatomist Georges Cuvier in his Recherche sur les Ossements Fossiles (Cuvier, 1824, p. 160, pl. 6, fig. 9) (Fig. 2.3). In this work as well as in the later

Figure 2. Mosasaurids from the Late Campanian Meudon Chalk (France). The Cuvier's tooth: 1-2, MNHN 8711, original specimen in labial and lingual views. Note on the lingual view the black ink inscription: "C (for Cuvier) pI VI f. (for figure) 9. Craie de Meudon"; 3, drawing by Cuvier (1824, pl. 6, fig. 9); 4, drawing by Gervais (1848-1852, pl. 60, fig. 6). The d'Orbigny's specimens: 5, 7, cast of a fragment of jaw (now lost) and its drawing by Gervais (1848-1852, pl. 60, fig. 2 (Note that because of the reproduction process at this time it appears as a mirror); 6, 8, cast of a fragment of jaw (now lost) and its drawing by Gervais (1848-1852, pl. 60, fig. 1); 9, drawing of an isolated tooth (now lost) figured by Gervais (1848-1852, pl. 60, fig. 9); 10, drawing of a tooth being part of the jaw fragment (E-G) figured by Gaudry (1892, fig. 1); 11, drawing of an isolated tooth (now lost) found with the jaw fragment (E-G) figured by Gaudry (1892, fig. 2). 12, MNHN Gg2004/5569, unpublished isolated tooth (figured here for the first time) that could correspond to one of the three isolated teeth found by d'Orbigny, but not the one figured by Gervais (I) nor the one by Gaudry (K). The Gervais's specimens: 13, drawing of an isolated tooth (now lost) figured by Gervais (1848-1852, pl. 60, fig. 7); 14, drawing of an isolated tooth (now lost) figured by Gervais (1848-1852, pl. 60, fig. 8); 15, drawing of an isolated tooth (now lost) figured by Gervais (1848-1852, pl. 59, fig. 25). The Hébert's tooth: 16, drawing of an isolated tooth (now lost) figured by Hébert (1855, pl. 27, fig. 1). The Gaudry's tooth: 17-18, MNHN 1892-11, original specimen and its drawing figured by Gaudry (1892, fig. 3). Other specimen preserved in the MNHN collections: 19, MNHN 1897-15, 9, unpublished isolated tooth (figured here for the first time). Scales bars $=2 \mathrm{~cm}$ in $1-4,12,17-18 ; 5 \mathrm{~cm}$ in $5-8$. Others drawings not at scale. 
(1)

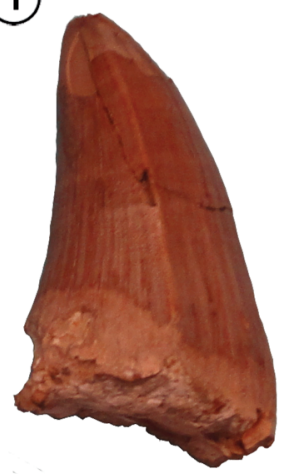

(2)

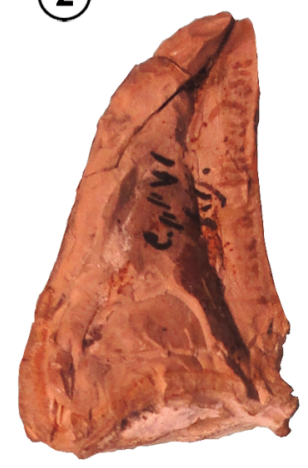

(3)

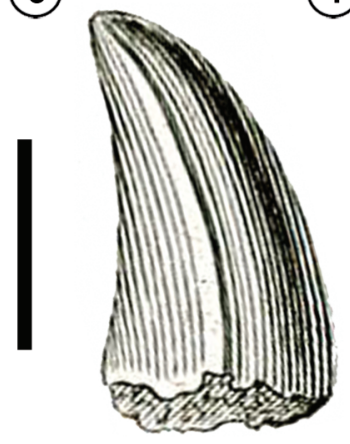

(4)

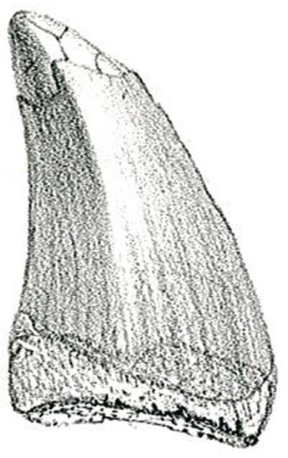

(9)

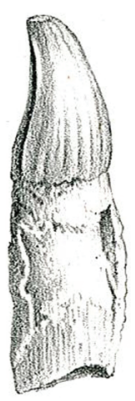

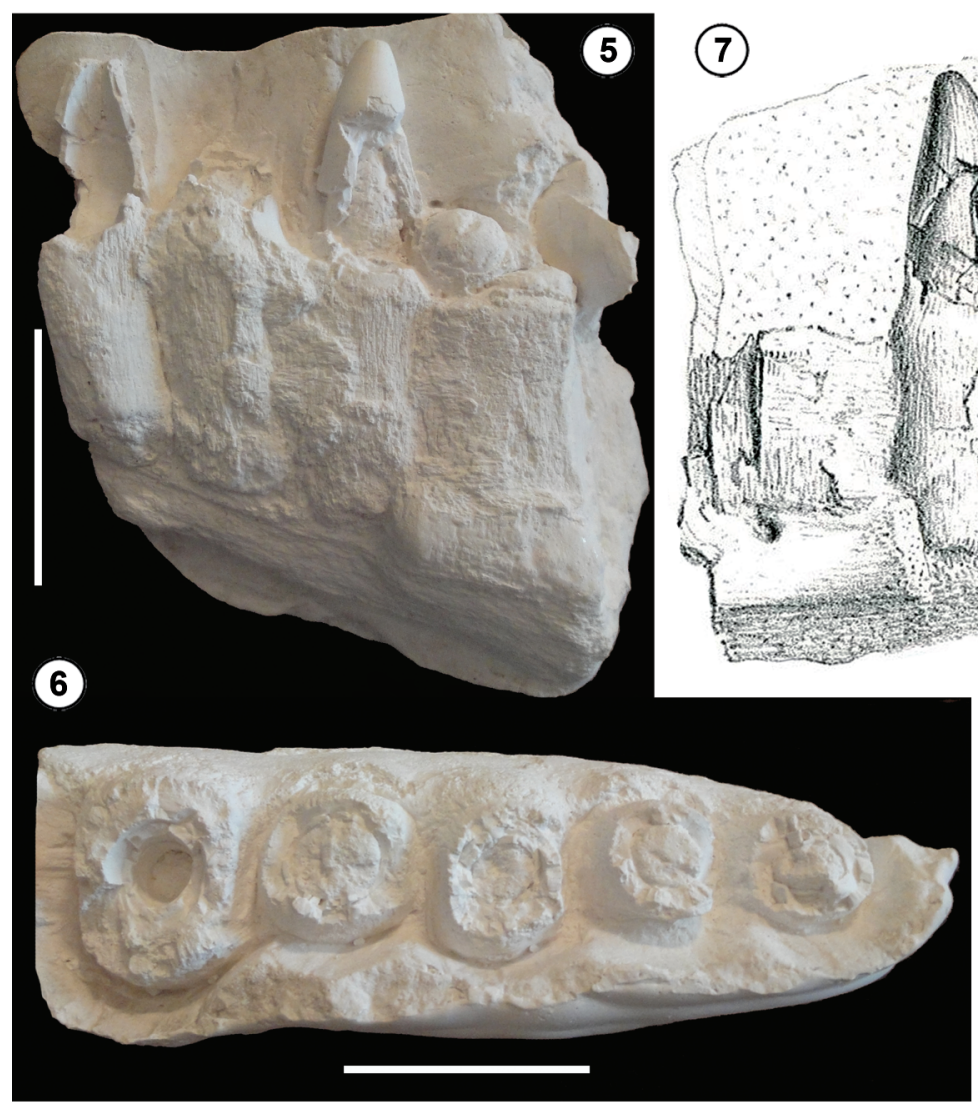

(8)

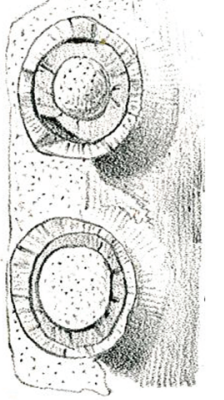

(10)

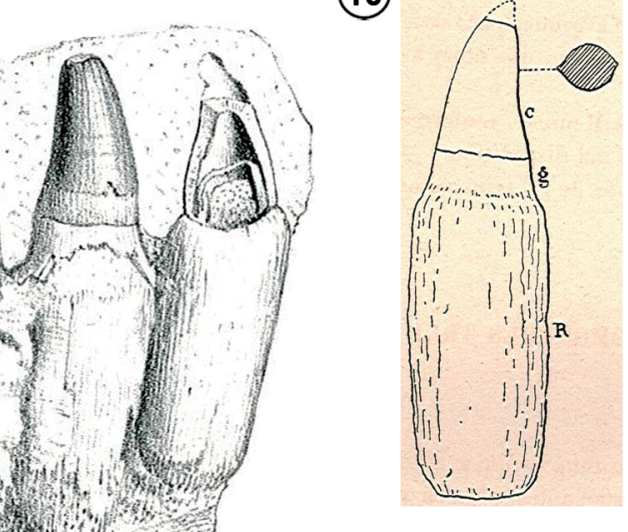

(11)

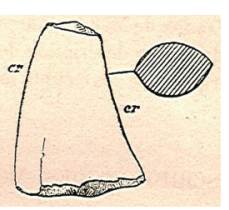

(12)

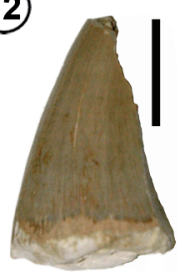

(13)

(14)

(15)

(16)

(17)

(18)
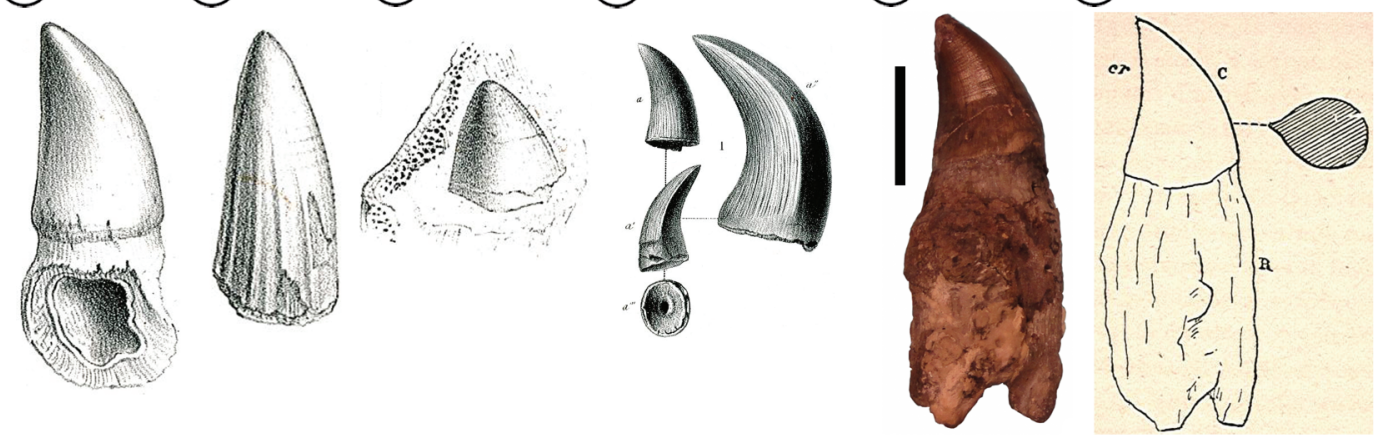

(19)

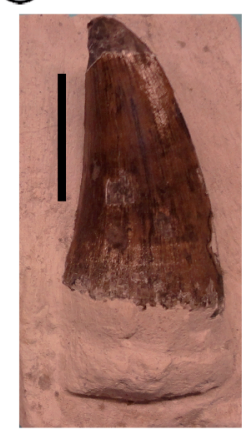


editions (Cuvier, 1836), he dedicated only a short descriptive paragraph to this tooth and referred it invariably to a crocodile. He wrote (Cuvier, 1824, p. 160): "D'une dent de crocodile de la craie de MEUDON. Elle m'a été donnée par M. Brongniart, et je la représente, pl. VI, fig. 9. Elle est fendue longitudinalement, et on n'en possède qu'une moitié. Son diamètre à la base est de 0,027, et sa hauteur de 0,04. sa forme, sa courbure, l'arête légère qui règne sur un de ses côtés, la rendent très-semblable à celle des crocodiles ordinaires. L'individu dont elle provient devoit être long à peu près de vingt pieds" [On a crocodile tooth from the MEUDON Chalk. It has been given to me by Mr. Brongniart, and I represent it, pl. VI, fig. 9. It is longitudinally splited, and we have only half of it. Its basal diameter is 0.027, and its height 0.04. Its shape, its curvature, the slight ridge occurring on one of its side, renders it very similar to that of ordinary crocodiles. The individual from which it comes should have been about twenty feet long].

As underlined by Gaudry (1892, p. 10-11), it is rather surprising that Cuvier, who was the first to interpret mosasaurids as squamates in his detailed description of the Grand Animal Fossile des Carrières de Maestricht (Cuvier, 1808) -holotype of the first mosasaurid historically named (Mosasaurus hoffmannii) - didn't recognise the isolated Meudon tooth as a mosasaur and rather attributed it to a crocodile.

This tooth was then regarded by Gray (1831) as belonging to the crocodile Crocodilus brongniarti.

Gervais in his book Zoologie et Paléontologie françaises (Gervais, 1848-1852, Tome 1, p. 261 and Tome 2, p. 7) referred this tooth accurately to a mosasaur, namely to Mosasaurus camperi (= Mosasaurus hoffmannii) and figured it (Gervais, 1848-1852, pl. 60, fig. 6) (Fig. 2.4).

Later, for an obscure and unknown reason, Hébert (1855, p. 346) wrote that the tooth figured by Gervais (1848-1852, pl. 60, fig. 6) was not the one described by Cuvier (1824, pl. 6, fig. 9). He thus described it differently and referred the Cuvier's tooth to Crocodilus brongniarti and the (supposed) Gervais's one to Mosasaurus sp.! Though Cuvier drawing is indeed approximate (Fig. 2.3), his description though brief- is perfectly clear, leading to no possible confusion: as mentioned by Gaudry (1892, p. 10-11), a view we recently confirmed (Bardet, 2012), the tooth described by Cuvier and the one figured by Gervais are the same.
Moreover, MNHN 8711 fits perfectly with Gervais's drawing (Fig. 2; compare 1, 3 and 4) and on the broken side of the tooth is vertically written with black ink the references of Cuvier ('C.'), of his plate ('pl VI') and figure ('f'), as well as the occurrence of the tooth (the Meudon Chalk) as follows: "C. pl VI f. 9. Craie de Meudon". This tooth has been referred to Hainosaurus sp. by Bardet (2012, p. 39).

\section{The Charles d'Orbigny's specimens}

In 1836, the naturalist Charles d'Orbigny, brother of Alcide d'Orbigny wrote (1836, p. 282): "Dans la craie blanche exploitée, que l'on voit à la partie la plus inférieure du terrain de Meudon, j'ai recueilli, à une assez grande profondeur, non seulement plusieurs grosses dents de Crocodiles, mais de plus, un fragment de Poisson et une Tortue marine ayant environ 15 pouces de long. Ce dernier reptile, que malheureusement je n'ai pu avoir qu'en fragmens, à cause de son peu de consistance, n'avait point encore été cité dans la craie blanche" [In the exploited white chalk, that is visible at the lowermost part of the Meudon series, I have found, at a considerable depth, not only several large crocodilian teeth, but also, a Fish and a marine Turtle fragments, this last one being about 15 inches long. This last reptile, that unfortunately I have been able to recover only fragments, because of his lack of consistency, had not yet been mentioned in the white chalk].

A year later, in a report about the different stratigraphical levels around Paris, from the basalmost Campanian Chalk to the uppermost Sparniacian Plastic Clays (Fig. 1.3), he mentioned again that he found in the exploited basal White Chalk of Meudon a fish fragment, a turtle fragment (same sentences than in 1836) and "une partie de mâchoire garnie de ses dents et quelques autres os d'un grand Saurien qui, suivant M. Laurillard, est analogue au Mosasaurus de la craie de Maestricht" [a part of a jaw with its teeth and some other bones of a large Saurian which, according to M. Laurillard, is similar to the Mosasaurus of the Maestricht chalk] (d'Orbigny, 1837, p. 5). He also mentioned in the basal conglomerate of the Plastic Clay Formation, several fossils reworked from the Chalk, including mosasaurid ones, that were "Trois dents et une tête ou partie supérieure d'humérus d'un grand saurian, très voisin du Mosasaurus ou Monitor de la craie de Maëstricht" [three teeth and one head or proximal portion of an humerus of a large saurian, very close to the Mosasaurus 
or Monitor of the Maëstricht Chalk] (d'Orbigny, 1837, p. 12).

In total, at least one jaw fragment with teeth, three isolated teeth, part of a limb bone and other mosasaurid fragments were found by Charles d'Orbigny in the Meudon Chalk, the whereabouts of most of them being unfortunately currently unknown (see details below).

A decade after, Gervais described and figured, firstly as Mosasaurus (Gervais, 1847, p. 544, fig. 217), then as Leiodon anceps (Gervais, 1848-1852, Tome 1, p. 262 and Tome 2, p. 7, pl. 60, figs. 1-2), two jaw fragments found by d'Orbigny in the Meudon Chalk (Fig. 2.7-8). These jaw fragments most probably correspond to the specimens d'Orbigny referred as "une partie de mâchoire garnie de ses dents et quelques autres os d'un grand Saurien qui, suivant M. Laurillard, est analogue au Mosasaurus de la craie de Maestricht' [a part of a jaw with its teeth and some other bones of a large Saurian which, according to M. Laurillard, is similar to the Mosasaurus of the Maestricht chalk] (d'Orbigny, 1837, p. 5). Indeed, two evidences in Gervais's texts support this hypothesis: 1, the similitude of the d'Orbigny's and Gervais's sentences when referring to these specimens, notably the mention of Laurillard's identification. Gervais wrote: 1, "C'est également I'opinion que l'on a d'abord eue au sujet de quelques pieces ( $p$ l. 61, fig. 1-2) qui sont de la craie de Meudon. M. Laurillard les a considérées comme étant du Mosasaure, et c'est ainsi que je les ai moi-même indiquées dans la Zoologie de la France; mais, après un nouvel examen, j'ai été conduit à les rapporter au genre Léiodon de M. Owen" [It is also the view that we first had about some specimens (pl. 61, fig. 1-2) that are from the chalk of Meudon. Mr. Laurillard considered them as belonging to the Mosasaur, and this is how I myself have stated them in the Zoologie de la France; but after newly examine them, I was driven to report them to the genus Léiodon of Mr. Owen] (Gervais, 1848-1852, p. 262); 2, Gervais mentioned two specimens deposited by d'Orbigny in the MNHN collections. He wrote: "Des deux morceaux qui ont été déposés au Muséum de Paris par les soins de M. Ch. D'orbigny, I'un (pl. 60 , fig. 1) porte trois dents en place, dont deux presque entières; l'autre laisse voir la coupe des racines de cinq dents en rangées, lesquelles ont été cassées au collet (j'en figure deux pl. 60, fig. 2); ces cinq dents occupaient ensemble une longueur de $0^{m}, 13$, ce qui indique une taille inférieure à celle du Mosasaurus; elles appartiennent à la mâchoire inférieure" [Of the two speci- mens that were deposited at the Muséum of Paris under the care of M. Ch. d'Orbigny, one (pl. 60, fig. 1) bears three teeth in place, including two almost intact; the other specimen reveals the root cutting of five teeth in row, which have been broken at the base (I figure two pl. 60, fig. 2); these five teeth together occupied a length of $0^{m}, 13$, which indicates a size smaller than that of the Mosasaurus; they belong to the lower jaw] (Gervais 1848-1852, p. 262).

Unfortunately, these specimens have not been currently located in the MNHN collections, though they were available in the Geology collections in the 1980. But, at this time, casts (Fig. 2.5-6) were fortunately made (A.G., pers. obs.). These casts fit perfectly with both the description and the measurements provided by Gervais above mentioned. Here, pending the possible rediscovery in the MNHN collections of the original specimens, we figure the casts as unique testimonies of these historical remains. Note that: 1 , the first fragment, only partially figured by Gervais (Fig. 2.8), is completely figured here for the first time (Fig. 2.6); 2, the second fragment was more complete at Gervais's time (Fig. 2.7) that in the 1980 when the cast was made, the middle tooth appearing as broken on it (Fig. 2.5).

Gervais (1848-1852, pl. 60, fig. 9) finally figured an isolated tooth as coming from the d'Orbigny collection (Fig. 2.9), which whereabouts is currently unknown. Gaudry (1892, p. 3 , footnote $n^{\circ} 2$ ) mentioned that this tooth (as well as the one figured by Gervais on his pl. 60, fig. 8) was very similar by their facets to those of Prognathosaurus (= Prognathodon solvayi) from the Brussels Museum. As nor Gervais neither Gaudry provided any detailed description of this tooth, it is not possible, on the basis of the Gervais's drawing only, to refer it to a precise taxon.

Later, concerning the above mentioned jaw fragments, Gaudry wrote: "Charles d'Orbigny, qui a tant contribué à faire connaitre la géologie des environs de Paris, a trouvé dans la craie blanche à Belemnitella mucronata de Meudon deux mâchoires et une dent isolée provenant sans doute du Liodon anceps. Paul Gervais les a décrites et figurées. M. Stanislas Meunier, en me les communiquant, m'a autorisé à les dégager de la craie où elles étaient en partie cachées. Mon ami M. Marcellin Boule a eu l'obligeance de me faire des croquis de grandeur naturelle d'une des dents enfoncées dans la mâchoire (fig. 1) et d'une dent isolée (fig. 2). (...). Sur un des morceaux de 
mâchoires de Liodon anceps recueillis par Charles d'Orbigny, on voit des alvéoles de dimensions très inégales, dont l'un indique une dent aussi forte que celle de ma figure 2" [Charles d'Orbigny, who contributed so much to make known the around Paris geology, found in the Belemnitella mucronata white chalk of Meudon two jaws and a single tooth probably referable to Liodon anceps. Paul Gervais described and figured them. M. Stanislas Meunier, when communicating them to me, allowed me to remove them from the chalk where they were still hidden. My friend M. Marcellin Boule was kind enough to make for me some natural-size sketches of a tooth embedded in the jaw (fig. 1) and of an isolated tooth (fig. 2). (...). On one of the jaw fragment collected by Charles d'Orbigny, very unequal in size alveoli are visible, one of which indicating teeth as strong as that of my figure 2] (Gaudry, 1892, p. 3-4).

At first sight Gaudry's figure 1 (Fig. 2.10) is confusing because, according to the previous text, it suggests that a tooth of the jaw fragment was removed from it, which is impossible. Fortunately Gaudry precised in his figure caption: "Dent du Liodon anceps qui fait partie d'un morceau de mâchoire où sa racine est complètement engagée" [tooth of the Leidon anceps that is part of a jaw fragment where its root is fully engaged] (Gaudry, 1892, p. 3). With its characteristic broken apex, it probably corresponds to the original second one of the serie, as figured by Gervais (compare Figs. 2.7 and 2.10), precisely the one broken on the cast (Fig. 2.5).

Gaudry's figure 2 tooth (Fig. 2.11) was possibly the one he said it was removed from the matrix. He mentioned in the figure caption (Gaudry, 1892, p. 3): "Dent postérieure de Liodon anceps, brisée en dessous de sa couronne, trouvée isolée en même temps que la mâchoire dont on voit une dent, fig. 1" [Posterior tooth of Liodon anceps, broken below the crown, found isolated with the jaw of which a tooth is visible on fig. 1]. This last tooth could thus correspond to one of the three teeth originally found by d'Orbigny (1836, 1837). This tooth, mentioned by Gaudry in the caption of figure 2 as preserved in the Geology collection of the Muséum (Gaudry, 1892, p. 3) has not currently been located and does not fit with MNHN Gg2004/5969 preserved in the Geology collections (Fig. 2.12, see below). It may thus correspond to the unique figuration of (possibly) one of three teeth found by d'Orbigny.
The systematical identification of these -now lost- jaw fragment and two isolated teeth remains difficult. As described and figured by Gervais and Gaudry and after examination of the casts of the jaw fragments, they could belong either to Hainosaurus sp. or to Prognathodon sp. on the basis of the tooth shape and ornamentation (N.B., pers. obs.). On the most complete jaw fragment cast, the only preserved tooth crown, the middle one, part of which is broken, is about $3.5 \mathrm{~cm}$ high and $2 \mathrm{~cm}$ wide at its base. It is stout, slightly posteriorly recurved and laterally compressed, and bears two anteriorly and posteriorly located carinae. The apex is broken but it may correspond to natural wear. The enamel appears smooth (but it could be due to the cast lacks of details) though minute striae seem to be present near the apex.

Finally, two specimens of the d'Orbigny collection are currently kept in the MNHN Geology collection. They could correspond to some of the original ones found by him but we cannot confirm this as no figure was provided. They are: MNHN Gg2004/5569 (Fig. 2.12), a tooth labelled "fragment de mâchoire de Leiodon anceps" [jaw fragment of Leiodon anceps] that could correspond to one of the three teeth found by d'Orbigny, but not the one figured by Gervais (1848-1852, pl. 60, fig. 9) (Fig. 2.9) nor the one figured by Gaudry (1892, fig. 2) (Fig. 2.11), mentioned by these authors as coming from the d'Orbigny's collection. If it is the case, it may correspond to the only of the three teeth found by d'Orbigny currently preserved, the whereabouts of the ones figured by Gervais and Gaudry being unknown. This tooth has been referred to Hainosaurus sp. by Bardet (2012, p. 39).

MNHN Gg2004/20773, an indeterminate fragment (not figured here) also labelled "fragment de mâchoire de Leiodon anceps" [jaw fragment of Leiodon anceps] that could correspond without any certainty to what d'Orbigny referred to "autres fragments d'os" [others fragments of bones] (d'Orbigny, 1836, 1837). Due to the very fragmentary status of this specimen, it is even impossible to confirm it belongs to a mosasaurid.

\section{The Paul Gervais's specimens}

Additionally to the Cuvier's and d'Orbigny's specimens, the paleontologist Paul Gervais (1848-1852) also figured three additional mosasaurid teeth from Meudon that he 
referred to respectively Mosasaurus camperi (Gervais, 18481852, pl. 60, figs. 7-8) and Leiodon anceps (Gervais, 18481852, pl. 59, fig. 25). Unfortunately no detailed description was given by Gervais so the following assignments, based on Gervais's figures, are only tentative.

The first one (Gervais, 1848-1852, pl. 60, fig. 7) was mentioned as coming from the private Duval's collection and its whereabouts is currently unknown (Fig. 2.13). It is a robust tooth, preserving both crown and root. The crown, triangle in lateral view, is slightly posteriorly recurved with a convex anterior face and an almost straight posterior one bearing a visible "pinched" carina; the crown base is slightly swollen; the enamel appears smooth. On the basis of this character combination (i.e., Lingham-Soliar and Nolf, 1989; Schulp et al., 2004) this tooth could belong to the mosasaurine Prognathodon.

The second one (Gervais, 1848-1852, pl. 60, fig. 8), specified as found by Gervais himself, has also not been found in the MNHN collections (Fig. 2.14). It looks different from the previous one and could belong to the tylosaurine Hainosaurus on the basis of the following characters: the crown is large and robust, only slightly posteriorly recurved with an almost straight posterior surface, about half long as high, and seems ornamented by both facets and fine striations and minutely serrated carinae (i.e., Lindgren and Siverson, 2002, and Lindgren, 2005 for details).

The third one (Gervais, 1848-1852, pl. 59, fig. 25) was mentioned by Gervais as kept in the School of Mines, which collections were given to the MNHN during the $20^{\text {th }}$ century; like the two previous ones, it has not been found in the MNHN collections (Fig. 2.15). Gervais indicated it was laterally compressed. From his drawing, it appears that only the upper part of the crown is preserved. It is a robust cone without any curvature and bearing two clearly serrated strong carinae. The apex is blunt and a rough ornamentation seems to be present. These characters fit generally well with the mosasaurine Prognathodon (see Bardet et al., 2005).

\section{The Edmond Hébert's specimens}

The third paleontologist to describe mosasaurid specimens from Meudon was Edmond Hébert, who made a PhD Thesis on the Meudon Chalk faunas. He is mostly known from his work on the mammal Coryphodon found in the
Cenozoic layers of Meudon, but also from his interesting paleogeographical hypotheses concerning the Paris Basin.

In 1855, Hébert provided a paper on the Meudon Chalk faunas in which he described briefly (and very confusedly!) three mosasaurid teeth: the 'Cuvier's tooth', the 'Gervais's tooth' and another tooth, newly discovered. It has been definitively demonstrated above that the 'Cuvier's tooth' and the 'Gervais's tooth' represent a unique and same tooth, that is, the one described by Cuvier (1824, pl. 6, fig. 9).

Consequently, this leads to the following questions: which tooth actually described Hébert as the 'Gervais' tooth? And where is it currently preserved? Concerning this last question, Hébert said that it was displayed in the MNHN (Hébert, 1855, p. 346) but we have not found it. Concerning the first question, he briefly described this tooth as: "La seconde est presque complètement lisse, comprimée d'avant en arrière, c'est à dire dans le plan de la courbure, et présentant, par consequent, ses arêtes tranchantes sur les faces antérieure et postérieure" [The second one is almost entirely smooth, compressed from front to back, that is in the curvature plane and showing, consequently, its cutting edges on the anterior and posterior faces] (Hébert, 1855, p. 346). "(...) ici, les deux surfaces sont sensiblement égales comme dans le genre Leiodon; seulement la taille considerable de cette dent et sa forme conique, pointue, recourbée en arrière, la distinguent très nettement de celles des Leiodon, qui toutes sont allongées, presque droites et à pointes très obtuses; mais si elle appartient en réalité au genre Mosasaure, ce qui ne me paraît pas démontré, elle constitue sans aucun doute une espèce différente de celle de Maestricht" [here the two surfaces are sensibly equal as in the genus Leiodon; but the considerable size of this tooth and its conical, pointed, posteriorly recurved shape, make it very different from those of Leiodon, which all are elongated, almost straight and with very obtuse apex; but if it belong actually to the genus Mosasaure, which does not appear to me clearly demonstrated, it is certainly different from that of the Maestricht species] (Hébert, 1855, p. 347).

As this tooth has not been found and as it was not figured it is difficult to assign it to a precise taxon. However, the description fits rather well with either Prognathodon or to Hainosaurus, but certainly not to Mosasaurus (N.B., pers. obs.).

Finally, interestingly Hébert described and figured a third tooth (Hébert, 1855, p. 346-347, pl. 27, fig. 1) (Fig. 2.16), 
that he confusedly considered very similar to the 'Cuvier's tooth' (and so referred it as the same species, that is Crocodilus brongniarti) though being convinced that it belongs in fact to a reptile close to Mosasaurus! He described it as: "Je n'ai point retrouvé la dent qui a été l'objet de l'examen de Cuvier; mais j'ai fait figurer (pl. XXVII, fig. 1), une dent analogue, moitié plus petite, recueillie à Meudon par M. G. Naissant. (...) la nôtre, qui est plus recourbée, a 25 millimètres de longueur sur 12 de diamètre maximum à la base, dont le contour est presque circulaire; elle montre en son centre une cavité assez étroite et peu profonde (fig. 1d). A peu de distance de la base, les bords deviennent tranchants sur les côtés externe et interne; la dent est alors comprimée transversalement, au lieu de l'être d'avant en arrière comme dans les Mosasaurus et les Leiodon, et la section de la partie moyenne (fig. 1e) montre que la surface antérieure est plus convexe et plus grande que la postérieure. Toute la surface de la couronne, dont l'émail est certainement intact, porte des plis de la grosseur d'un cheveu très fin, dont les uns, un peu plus forts, vont jusqu'à la pointe, et les autres s'arrêtent à des distances inégales, comme dans le genre Polyptychodon de M. Owen" [I have not found the tooth subject to the review of Cuvier; but I figured (pl. XXVII, fig. 1), a similar tooth, half smaller, collected at Meudon by M. G. Naissant. (...) Our tooth, which is more curved, is 25 millimeters long by 12 millimeters of maximum basal diameter, whose outline is nearly circular; it shows in the center a rather narrow and shallow cavity (fig. 1d). At a short distance from the base, the edges become sharp on the outer and inner sides; the tooth is then compressed transversely instead of being from front to back as in Mosasaurus and Leiodon, and the middle part of the section (fig. 1e) shows that the front surface is more convex and greater than the posterior one. The entire surface of the crown, which enamel is certainly intact, bears striae the size of a very thin hair, some of which, the strongest, run up to the apex, the others stopping at unequal distances, as in the genus Polyptychodon of M. Owen] (Hébert, 1855, p. 346-347).

Both description and figuration of this tooth, that was part of the G. Naissant's private collection which whereabouts is currently unknown, fit perfectly with the genus Plioplatecarpus (i.e., Lingham-Soliar, 1994), taxon to which it is here tentatively assigned.

\section{The Albert Gaudry's specimens}

The last author to have described mosasaurid material from Meudon is the paleontologist Albert Gaudry. Moreover than mentioning and figuring some teeth from the d'Orbigny collection (Gaudry 1892, figs. 1-2, see above), he described a new tooth found in the Meudon chalk by M. Gilland and given by him to the Museum (Gaudry, 1892, fig. 3).

This tooth is currently preserved in the MNHN collections of Paleontology under number MNHN 1892-11 (Fig. 2.17). It was described as such by Gaudry: "Je rapporte encore, mais avec plus de doute, au Liodon anceps, une dent isolée que M. Gilland a trouvée à Meudon dans la craie blanche et dont M. Boule a dessiné le croquis que l'on voit fig. 3. Cette dent est haute de $0^{m} 075$; la couronne finement émaillée a $0^{m} 030$ de haut; à sa base son diamètre longitudinal est de $0^{m} 022$ et son diamètre transversal de $0^{m} 018$. Elle est ronde en avant, elle n'a qu'une seule carène placée en arrière; ses crénelures se voient à l'oeil nu. Elle est crochue, avec sa pointe qui regarde en arrière. A mon avis, tandis que la dent dont on voit le croquis fig. 1 appartient au milieu de la mâchoire et que celle de la figure 2 est une dent postérieure, la dent fig. 3, serait la plus antérieure du même Liodon anceps, qui avait ainsi trois sortes de dents différentes. Je dois dire cependant que M. Dollo, à qui j'ai montré les échantillons des figures 2 et 3 trouve que le premier ressemble aux dents maxillaires de son genre Hainosaurus et que le second pourrait être une dent ptérygoïdienne d'un énorme individu appartenant aussi à /Hainosaurus. Je ne saurais distinguer le genre Liodon et le genre Hainosaurus, quand je ne vois pas leur inter-maxillaire, car jusqu'à présent l'allongement de cet os me semble le seul caractère qui les sépare" [I refer also, but with more doubt, to Liodon anceps, an isolated tooth that M. Gillard found at Meudon in the white chalk and which M. Boule draw the sketch visible on fig. 3 . This tooth is $0^{\mathrm{m}} 075$ high; the crown finely enamelled is 0m030 high; its basal longitudinal diameter is $0^{\mathrm{m}} 022$ and its transversal one is 0m018. It is rounded anteriorly, having only one carina posteriorly located; its crenulations are visible at naked eye. It is hooked, with its apex looking posteriorly. In my opinion, whereas the tooth whose sketch can be seen in fig. 1 belongs to the median part of the jaw, and that of figure 2 is a posterior tooth, the tooth of fig. 3 could be the more anterior of the same Liodon anceps, who thus had three different kinds of teeth. I must say however that, Mr. Dollo, to whom 
I showed the samples of figures 2 and 3, find that the first resembles the maxillary teeth of his genus Hainosaurus and the second one could be a pterygoid tooth of a huge individual belonging also to Hainosaurus. I am not able to distinguish the genus Liodon from the genus Hainosaurus if I don't see their inter-maxillary, because until now the lengthening of this bone seems to me the only character that separates them] (Gaudry, 1892, p. 4) (Fig. 2.18). This text points out interestingly, not only the exchanges of ideas and opinions between these $19^{\text {th }}$ century palaeontologists, but also their modesty.

As suggested by Dollo, this tooth could belong to Hainosaurus and be rather a pterygoid one, a view confirmed recently by Bardet (2012).

\section{Additional specimens kept in the MNHN of Paris collection}

Additional undescribed mosasaurid isolated teeth from Meudon are kept in the MNHN (but also in some regional French museums, N.B. pers. obs.), in both the collections of Palaeontology and Geology. They are: 1, MNHN 1897-15 (Fig. 2.19) is an isolated tooth still imbedded on its chalk matrix labelled "Leiodon anceps, dents, données par M. Gittand et Lemoine" [Leiodon anceps, teeth, given by M. Gittand and Lemoine]. It exhibits all the characters above mentioned for Hainosaurus to which it is here referred; 2, MNHN Gg2004/ 20774, is also an isolated tooth still imbedded on a chalk block, labelled "Craie avec belemnite et dent de Leiodon, collection Vogèle" [Chalk with belemnite and Leiodon tooth, Vogèle collection]. Only part of the crown is visible on anterior view. It is high and robust and exhibits a strong carina and basal facets and striae, all characters permitting to refer it also to Hainosaurus.

\section{DISCUSSION}

From all the historical mosasaurid specimens found during the $19^{\text {th }}$ century and described by most famous French paleontologists of that time, only a tiny part is still preserved nowadays. In total, of the 15 specimens mentioned in this work, only the teeth described by Cuvier and Gaudry have been localized in the collections of Paleontology and Geology of the MNHN of Paris, the whereabouts of the other ones, especially the ones mentioned as kept in private $19^{\text {th }}$ century collections, being unknown. On the contrary, unpublished probably more recently found specimens are also kept in the MNHN collections.

On a systematical point of view, most of the teeth from the Late Campanian White Chalk of Meudon were previously (Bardet, 2012) or are in this work referred to the tylosaurine Hainosaurus sp. because of their general morphology and enamel crown ornamentation. This taxon has been shown to be present only in Europe, both in the Early Campanian of Sweden and in the Early Maastrichtian of Belgium; the others species previously attributed to Hainosaurus has been reassigned to Tylosaurus (see Lindgren and Siverson, 2002, and Lindgren, 2005 for details). Its occurrence in the Late Campanian of the Paris Basin makes thus a link between the Hainosaurus found earlier in Sweden and later in Belgium. On the basis of the original descriptions and/or figurations of Gervais, Gaudry and Hébert of the now lost specimens, the genera Plioplatecarpus and possibly Prognathodon were also present in this fauna.

Marine vertebrate remains are very scarcely found, always as isolated elements, in the Late Campanian White Chalk of Meudon and the bulk is represented by mosasaurid teeth. Both the historical specimens (most being lost nowadays) as well as additional specimens preserved currently in the MNHN of Paris represent thus precious and unique witnesses of a lost world so dear to Cuvier.

\section{ACKNOWLEDGMENTS}

This work is dedicated to Prof. Dr. Zulma Gasparini, who first author always considered as her "scientific mother". N.B. would like to pay a special tribute to Zulma Gasparini for being a pioneer and a figurehead woman in the field of South America Vertebrate Palaeontology, a model for generations of young paleontologists in Argentina (and elsewhere), and more especially a leader of Mesozoic marine reptile discoveries and studies. She converted the -almost unknown in the 1970-1980 decades- faunas from the Jurassic of the Neuquén Basin into the currently best known marine reptiles faunas from South America, mirroring the famous historical Jurassic ones from Europe. Also more personally, N.B. would like to emphasize the human aspects of Zulma's character, being a dynamic, opened mind and wise paleontologist, as well as a kind, warmhearted and very pleasant woman. N.B. was lucky to meet Zulma and to work with her several times and it was every time a renewed pleasure! We thanks J.-Y. Reynaud, C. Noyes, D. Brabant (Geology collections), as well as R. Allain, C. Sagne and V. Pernègre (Paleontology collections) to facilitate access to the collections of the MNHN of Paris. Special thanks to X. Pereda Suberbiola (Universidad del País Vasco, Bilbao) for improving the Spanish summary. Last but not least, we warmly thank M. Fernández (Museo de La Plata, Argentina) and Y. Herrera (Bayerische Staatssammlung für Paläontologie und Geologie, München, Germany) for kindly invited us to contribute to this volume, for revising the manuscript and for their editorial support. 


\section{REFERENCES}

Bardet, N. 2012. The mosasaur collections of the Muséum National d'Histoire Naturelle of Paris. Bulletin de la Société Géologique de France 183: 35-53.

Bardet, N., Pereda Suberbiola, X., larochène, M., Amalik, M., and Bouya, B. 2005. Durophagous Mosasauridae (Squamata) from the Upper Cretaceous phosphates of Morocco, with the description of a new species of Globidens. Netherlands Journal of Geosciences 84: 167-175.

Bardet, N., Falconnet, J., Fischer, V., Houssaye, A., Jouve, S., Pereda Suberbiola, X., Perez-Garcia, A., Rage, J.-C., and Vincent, P. 2014. Mesozoic marine palaeobiogeography in response to drifting plate. Gondwana Research 26: 869-887.

Bardet, N., and Buffetaut, E. 2011. [Field Guide to Meudon. In: Dinosaurs, their kith and kin: a historical perspective, Paris (France), May $3^{\text {rd }}-6^{\text {th }}$. Unpublished.].

Cappetta, H. 1987. Mesozoic and Cenozoic Elasmobranchii, Chondrichthyes II. In: H.P. Schultze (Ed.), Handbook of paleoichthyology. Gustav Fischer Verlag, Stuttgart, p. 1-193.

Corral, J.-C., Bardet, N., Pereda-Suberbiola, X., and Cappetta, H. 2012. First occurrence of the sawfish Onchosaurus from the Late Cretaceous of Spain. Journal of Vertebrate Paleontology 32: 212-218.

Cuvier, G. 1808. Sur le Grand Animal Fossile des Carrières de Maestricht. Annales du Muséum National d'histoire Naturelle, Paris 12: 145-176.

Cuvier, G. 1824. Recherches sur les ossemens fossiles de quadrupèdes, où l'on rétablit les caractères de plusieurs espèces d'animaux que les révolutions du globe paroissent avoir détruites. Librairie Déterville, Paris, 2ème Edition, Tome 5, Part 2, 151 p., pl. 6.

Cuvier, G. 1836. Recherches sur les ossemens fossiles de quadrupèdes, où l'on rétablit les caractères de plusieurs espèces d'animaux que les révolutions du globe paroissent avoir détruites. Librairie Déterville, Paris, 4ème Edition, Tome 2, 503 p.

Cuvier, G., and Brongniart, A. 1811. Essai sur la géographie minéralogique des environs de Paris, avec une carte géognostique, et des coupes de terrain. Baudouin, Paris, 278 p., 2 pl., 1 map.

d'Orbigny, C. 1836. Note sur le terrain nouvellement découvert à Meudon. Bulletin de la Société Géologique de France 1: 280-291.

d'Orbigny, C. 1837. Mémoire sur diverses couches de terrain nouvellement découvertes aux environs de Paris entre la craie et l'argile plastique. Bourgogne \& Martinet, Paris, p. 1-16.

Gaudry, A. 1892. Les Pythonomorphes de France. Mémoires de la Société Géologique de France (Paléontologie) 10: 1-13.

Gervais, P. 1847. La Zoologie de la France. In: Patria. La France ancienne et moderne, morale et matérielle, ou collection encyclopédique et statistique de tous les faits relatifs à l'histoire physique et intellectuelle de la France et de ses colonies, Paris. J.-J. Dubochet, Lechevalier \& Cie, Paris, Tome 1, p. 544, fig. 217.

Gervais, P. 1848-1852. Zoologie et paléontologie françaises (animaux vertébrés) ou nouvelles recherches sur les animaux vivants et fossiles de la France. Librairie Arthus Bertrand, Paris, Tome 1, p. 6-7, 261-262, pls. 59-60.
Gray, J.E. 1831. A synopsis of the species of class Reptilia. In: E. Griffith, and E. Pidgeon (Eds.), The animal kingdom arranged in conformity with its organisation by the Baron Cuvier with additional descriptions of all the species hitherto named, and of many before noticed. Whittaker, Treacher and Co., London, 481+110 p.

Hébert, E. 1855. Tableau des fossiles de la craie de Meudon et description de quelques especes nouvelles. Mémoires de la Société Géologique de France 2: 345-374.

Lindgren, J. 2005. The first record of Hainosaurus (Reptilia: Mosasauridae) from Sweden. Journal of Paleontology 79: 1157-1165.

Lindgren, J., and Siverson, M. 2002. Tylosaurus ivoensis: a giant mosasaur from the early Campanian of Sweden. Transactions of the Royal Society of Edinburgh, Earth Sciences 93: 73-93.

Lingham-Soliar, T. 1994. The mosasaur Plioplatecarpus (Reptilia, Mosasauridae) from the Upper Cretaceous of Europe. Bulletin de I' Institut Royal des Sciences Naturelles de Belgique, Sciences de la Terre 64: 177-211.

Lingham-Soliar, T., and Nolf, D. 1989. The mosasaur Prognathodon (Reptilia, Mosasauridae) from the Upper Cretaceous of Belgium. Bulletin de I'Institut Royal des Sciences Naturelles de Belgique, Sciences de la Terre 59: 137-190.

Mantel, G.A. 1829. A tabular arrangement of the organic remains of the county of Sussex. Transactions of the Geological Society, London 2: 201-216.

Schulp, A.S., Jagt, J.W.M., and Fonken, F. 2004. New material of the mosasaur Carinodens belgicus from the Upper Cretaceous of The Netherlands. Journal of Vertebrate Paleontology 24: 744-747.

Schulp, A.S., Polcyn, M.J., Mateus, O., Jacobs, L.L., and Morais, M.L. 2008. A new species of Prognathodon (Squamata, Mosasauridae) from the Maastrichtian of Angola, and the affinities of the mosasaur genus Liodon. Second Mosasaur Meeting. Proceedings of the Fort Hays Studies, Special Issue 3: 1-12.

Taquet, P. 2009. Les contributions respectives de Georges Cuvier et d'Alexandre Brongniart à l'élaboration de l'Essai sur la géographie minéralogique des environs de Paris, d'après les manuscrits retrouvés d'Alexandre Brongniart. Travaux du Comité Français d'Histoire de la Géologie, $3^{\text {ème }}$ série, 23: 1-16.

Recibido: 20 de agosto 2015

Aceptado: 21 de octubre 2015 